\title{
Performance of Activated Carbon Supported Cobalt Oxides and Iron Oxide Catalysts in Catalytic Cracking of Waste Cooking Oil
}

\author{
Tavayogeshwary Thangadurai ${ }^{1}$, Ching Thian Tye ${ }^{1 *}$ \\ ${ }^{1}$ School of Chemical Engineering, Engineering Campus, Universiti Sains Malaysia, 14300 Nibong Tebal, Pulau Pinang, Malaysia \\ *Corresponding author, e-mail: chcttye@usm.my
}

Received: 22 July 2020, Accepted: 15 February 2021, Published online: 13 May 2021

\begin{abstract}
This work studied the catalyst activity of activated carbon (AC) supported Co, Fe and Co-Fe oxides in catalytic cracking of waste cooking oil. Reactions were carried out in a fixed bed reactor at $450{ }^{\circ} \mathrm{C}$ with WHSV $9 \mathrm{hr}^{-1}$. Single metal Co/AC and Fe/AC catalysts with different metal loading (2.5-15 wt.\%) and bimetal $x$ Co-yFe/AC $(x, y=2.5$ to $12.5 \mathrm{wt} . \% ; x+y=15 \mathrm{wt} . \%)$ catalysts were investigated. $\mathrm{Co} / \mathrm{AC}$ and Fe/AC catalysts both contributed to significant liquid yield with high selectivity towards $\mathrm{C}_{15}$ and $\mathrm{C}_{17}$ hydrocarbons. Fe/AC catalysts gave high $\mathrm{C}_{5}-\mathrm{C}_{20}$ hydrocarbon yield whereas $\mathrm{Co} / \mathrm{AC}$ attained more palmitic $\left(\mathrm{C}_{16}\right)$ and oleic $\left(\mathrm{C}_{18}\right)$ acid conversion. Synergistic effect in two metals Co-Fe/AC catalysts had further improved the liquid hydrocarbon yield (up to $93 \%$ ) and fatty acid conversion (up to $94 \%$ ). The best catalyst, 10Co-5Fe/AC had been further tested under the effect of reaction temperature, feed flow rate (WHSV) and deactivation for its catalytic performance.
\end{abstract}

Keywords

renewable, waste cooking oil, catalytic cracking, activated carbon, metal oxide

\section{Introduction}

It is estimated that around 16.5 million tons of waste cooking oil (WCO) is generated every year worldwide [1]. These oils could harm the environment if they are not being handled properly before disposal. Recently, WCO is found to be a potential feedstock for green fuel production. It is more economical than using fresh vegetable oil as a feedstock and does not affect other applications such as competing with human consumption [2]. In the production of liquid biofuel, catalytic cracking process is favored over other approach due to its lower energy consumption relatively [3]. This reaction is usually catalyzed by metal oxides, molecular sieves, zeolites, activated alumina and sodium carbonate [4]. Recently, waste-derived carbon material [5], such as activated carbon (AC) and carbon nanotube (CNT), with high surface area and porous structure catalyst have received attention in the catalytic cracking reaction [6] due to a better catalytic performance. It was reported that conversion of WCO and liquid product yield were to be higher by using activated carbon compared to that of HZSM-5 catalyst [7]. Activated carbon also had more reaction active sites than MCM-41 in catalytic cracking of WCO to produce higher fuel range liquid product with lower oxygenated compounds due to better deoxygenation $[8,9]$. Furthermore, using activated carbon supported $\mathrm{MgO}$ generated higher $\mathrm{C}_{15}(8.1 \mathrm{wt} . \%)$ yield and $\mathrm{C}_{17}$ (10.2 wt.\%) yield compared to silica, alumina, and zirconia as the support in catalytic cracking of WCO [10].

In catalysis, metal oxides provide acid and/or basic sites for the reactions and the active metal phase is anchored to highly porous support with large surface area [11]. Cobalt oxide promotes decarboxylation and decarbonylation to produce paraffinic and olefinic hydrocarbons, respectively [12]. Cobalt supported on activated carbon produced $91 \%$ of $\mathrm{C}_{8}-\mathrm{C}_{20}$ hydrocarbons with $72 \%$ of $\mathrm{n}-\left(\mathrm{C}_{15}+\mathrm{C}_{17}\right)$ selectivity in deoxygenation of palm fatty acid distillate via high decarboxylation and/or decarbonylation [13]. Incorporation of $\mathrm{Co}_{3} \mathrm{O}_{4}$ onto $\mathrm{La}_{2} \mathrm{O}_{3} / \mathrm{AC}$ catalyst increased the hydrocarbon yield and $\mathrm{n}-\left(\mathrm{C}_{15}+\mathrm{C}_{17}\right)$ selectivity as well. Catalytic cracking of WCO over $\mathrm{Co}_{3} \mathrm{O}_{4}-\mathrm{La}_{2} \mathrm{O}_{3} / \mathrm{AC}$ resulted in $96 \%$ of $\mathrm{C}_{8}-\mathrm{C}_{20}$ hydrocarbon yield with $93 \% \mathrm{n}-\left(\mathrm{C}_{15}+\mathrm{C}_{17}\right)$ selectivity [12].

On the other hand, activated carbon-doped Fe produced liquid biofuel with properties specified by the ASTM 
standards in catalytic cracking of WCO [6]. $\mathrm{NiO}-\mathrm{Fe}_{2} \mathrm{O}_{3} /$ MWCNT catalyst contributed $89 \%$ of $\mathrm{C}_{8}-\mathrm{C}_{12}$ hydrocarbon yield and $79 \% \mathrm{n}-\left(\mathrm{C}_{15}+\mathrm{C}_{17}\right)$ selectivity with only traces of heavy compounds $\left(>\mathrm{C}_{20}\right)$. Incorporation of $\mathrm{Fe}_{2} \mathrm{O}_{3}$ onto $\mathrm{NiO} / \mathrm{MWCNT}$ increased $\mathrm{n}-\left(\mathrm{C}_{8}-\mathrm{C}_{12}\right)$ hydrocarbons formation (49\%) via its high cracking activity. The liquid product obtained met the specifications designated for ultra-low-sulfur diesel in terms of flash point, cloud point, pour point and cetane index [14].

These research works showed that activated carbon supported transition metal oxide has a good potential in catalytic cracking activity. Co oxide and Fe oxide incorporation has improved the performance of the activated carbon-based catalysts. This work studies the synergistic effect between the combination of Co-Fe oxides and their individual contribution in the catalytic cracking activity. Particularly, the effects of different metal loading and bimetal ratio in catalysts, as well as operating conditions during the catalytic cracking reaction.

\section{Experimental}

\subsection{Materials}

WCO was collected from the cafeteria in the university campus. Coconut shell-based activated carbon was supplied by Kekwa Indah Carbon Solutions Sdn. Bhd. Cobalt (II) nitrate hexahydrate, $\mathrm{Co}\left(\mathrm{NO}_{3}\right)_{2} \cdot 6 \mathrm{H}_{2} \mathrm{O}(99.999 \%)$ and iron (III) nitrate nonahydrate, $\mathrm{Fe}\left(\mathrm{NO}_{3}\right)_{3} \cdot 9 \mathrm{H}_{2} \mathrm{O}(99.999 \%)$ were purchased from Sigma-Aldrich.

\subsection{Catalyst preparation}

AC obtained was pretreated with boiling nitric acid (69-70\% QREC) solution at $80^{\circ} \mathrm{C}$ overnight initially. Co and $\mathrm{Fe}(2.5-$ $15 \mathrm{wt} . \%$ ) were then incorporated onto AC via incipient wetness impregnation method, where the required amount of metal precursors (Co or/and $\mathrm{Fe}$ ) were dissolved in deionized water. AC was added into the aqueous solution and stirred at room temperature overnight. The catalysts prepared were then dried in an oven at $105^{\circ} \mathrm{C}$ and calcined at $550^{\circ} \mathrm{C}$ in nitrogen flow $(99.9995 \%)$ for 5 hours. The synthesized catalysts were denoted as $x$-Co/AC, $y$-Fe/AC, and $x \mathrm{Co}-y \mathrm{Fe} / \mathrm{AC}(x, y$ referred to metal loading in wt.\%).

\subsection{Characterization of catalyst}

$\mathrm{N}_{2}$ physisorption was conducted at $-196^{\circ} \mathrm{C}$ using BrunauerEmmett-Teller (BET) model in Micromeritics ASAP2020 to determine surface area and pore distribution of the catalyst. The sample was degassed at $150{ }^{\circ} \mathrm{C}$ for 24 hours prior to analysis to remove the moisture. The catalysts were also characterized using a Scanning Electron Microscopy (SEM) on FEI Quanta 450 FEG instrument operated at $5 \mathrm{kV}$. The SEM was equipped with energy dispersive X-ray (EDX) performed by Oxford Instruments X-Max.

\subsection{Catalyst activity test}

A continuous tubular reactor setup was used for the reaction. $1 \mathrm{~g}$ of catalyst was loaded inside the tubular reactor. $\mathrm{N}_{2}(99.9995 \%)$ as carrier gas was passed through the reactor via a mass flow controller (model M100B by MKS Instrument). A tube furnace (Nabertherm B170) was used to heat up the reactor. Once the reactor was heated up to the desired temperature, WCO was fed into the reactor by a metering pump (Lab Alliance Series I) at a set WHSV and the reaction was considered to start. The reactor outlet stream was condensed using cold water bath and was collected at interval of $30 \mathrm{mins}$ or $1 \mathrm{hr}$. Used catalyst was recovered from the reactor after it was allowed to cool down. The yield of coke, liquid and gaseous products were calculated as shown below:

Liquid yield $(w t . \%)=\frac{\text { Liquid product }(\mathrm{g})}{\text { Weight of oil fed }(\mathrm{g})} \times 100 \%$

Coke yield $($ wt. $\%)=$

$\frac{\text { Recovered solid material }(\mathrm{g})-\text { Fresh catalyst }(\mathrm{g})}{\text { Weight of oil fed }(\mathrm{g})} \times 100 \%$

Gas yield $($ wt. $\%)=100 \%-$ Liquid yield - Coke yield

\subsection{Liquid product analysis}

The liquid sample was diluted with hexane and analyzed using a gas chromatography with a flame ionization detector (GC-FID) (Agilent 7890A) which was equipped with a HP-5 column $(30 \mathrm{~m} \times 0.32 \mathrm{~mm} \times 0.25 \mu \mathrm{m})$. The detector was set at $300{ }^{\circ} \mathrm{C}$ with injection temperature at $250{ }^{\circ} \mathrm{C}$ and helium (99.999\%) at $1 \mathrm{ml} / \mathrm{min}$ served as carrier gas. Oven temperature was held at $40^{\circ} \mathrm{C}$ for 6 mins and subsequently ramped to $270{ }^{\circ} \mathrm{C}$ at a heating rate of $7^{\circ} \mathrm{C} \mathrm{min}{ }^{-1}$. The liquid product was calculated for its hydrocarbon yield and selectivity as follows [15]:

$$
\begin{aligned}
& \text { Hydrocarbon yield }(\%) \\
& =\frac{\text { Area of } \mathrm{C}_{5}-\mathrm{C}_{20} \text { hydrocarbons }}{\text { Total area }- \text { Area of hexane }} \times 100 \% \\
& \text { Selectivity of } \mathrm{C}_{n}(\%) \\
& =\frac{\text { Area of } \mathrm{C}_{n}}{\text { Area of } \mathrm{C}_{5}-\mathrm{C}_{20} \text { hydrocarbons }} \times 100 \%,
\end{aligned}
$$

where $n$ ranges from 5 to 20 . 


\section{Results and discussions}

\subsection{Characterization of catalyst}

The AC used had a high BET surface area of $1105 \mathrm{~m}^{2} \mathrm{~g}^{-1}$ and microporous structure with large porous volume of $0.45 \mathrm{~cm}^{3} \mathrm{~g}^{-1}$. It was expected of slight reduction in surface area with the loading of metals onto the AC [16].

Fig. 1 shows the $\mathrm{N}_{2}$ adsorption/desorption isotherm of $10 \mathrm{Co}-5 \mathrm{Fe} / \mathrm{AC}$. The catalyst exhibited type I isotherm with $\mathrm{P} /$ Po approaching 1 and $\mathrm{H} 4$ hysteresis loop which represented its microporous structure. It possesses BET surface area of $837.19 \mathrm{~m}^{2} \mathrm{~g}^{-1}$ and microporous surface area of $459.91 \mathrm{~m}^{2} \mathrm{~g}^{-1}$. The porous volume of $10 \mathrm{Co}-5 \mathrm{Fe} / \mathrm{AC}$ catalyst was identified to be $0.44 \mathrm{~cm}^{3} \mathrm{~g}$ with microporous volume of $0.22 \mathrm{~cm}^{3} \mathrm{~g}^{-1}$.

Fig. 2 shows the SEM image of $10 \mathrm{Co}-5 \mathrm{Fe} / \mathrm{AC}$ that exhibits a highly porous structure with microporosity $(<2 \mu \mathrm{m})$. The homogeneous distribution of $\mathrm{Co}$ and Fe metals on activated

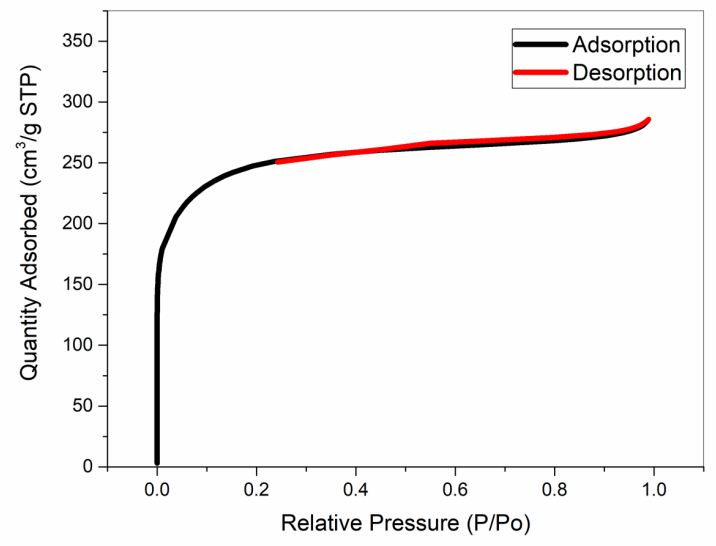

Fig. $1 \mathrm{~N}_{2}$ adsorption/desorption isotherm $10 \mathrm{Co}-5 \mathrm{Fe} / \mathrm{AC}$ catalyst
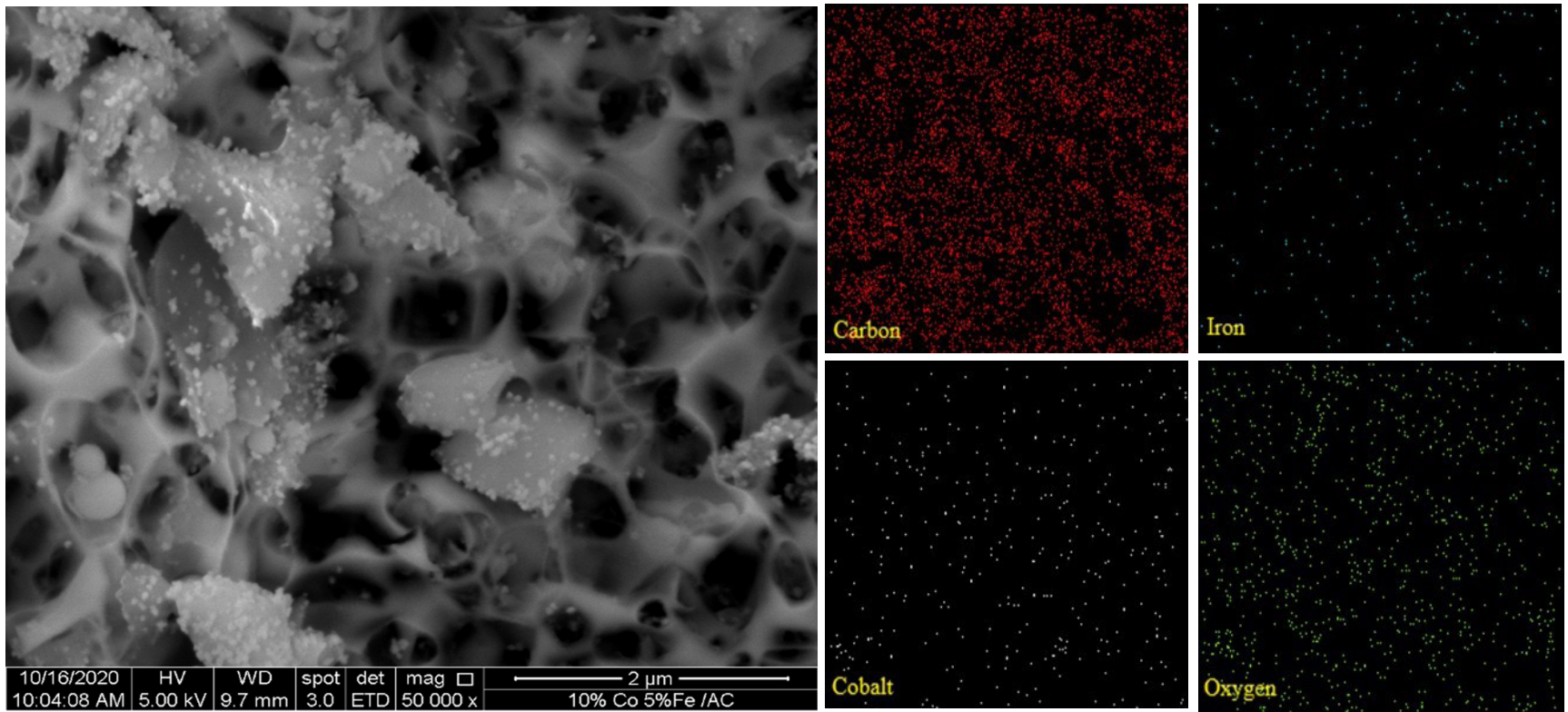

Fig. 2 SEM image and EDX mapping for $10 \mathrm{Co}-5 \mathrm{Fe} / \mathrm{AC}$ catalyst 


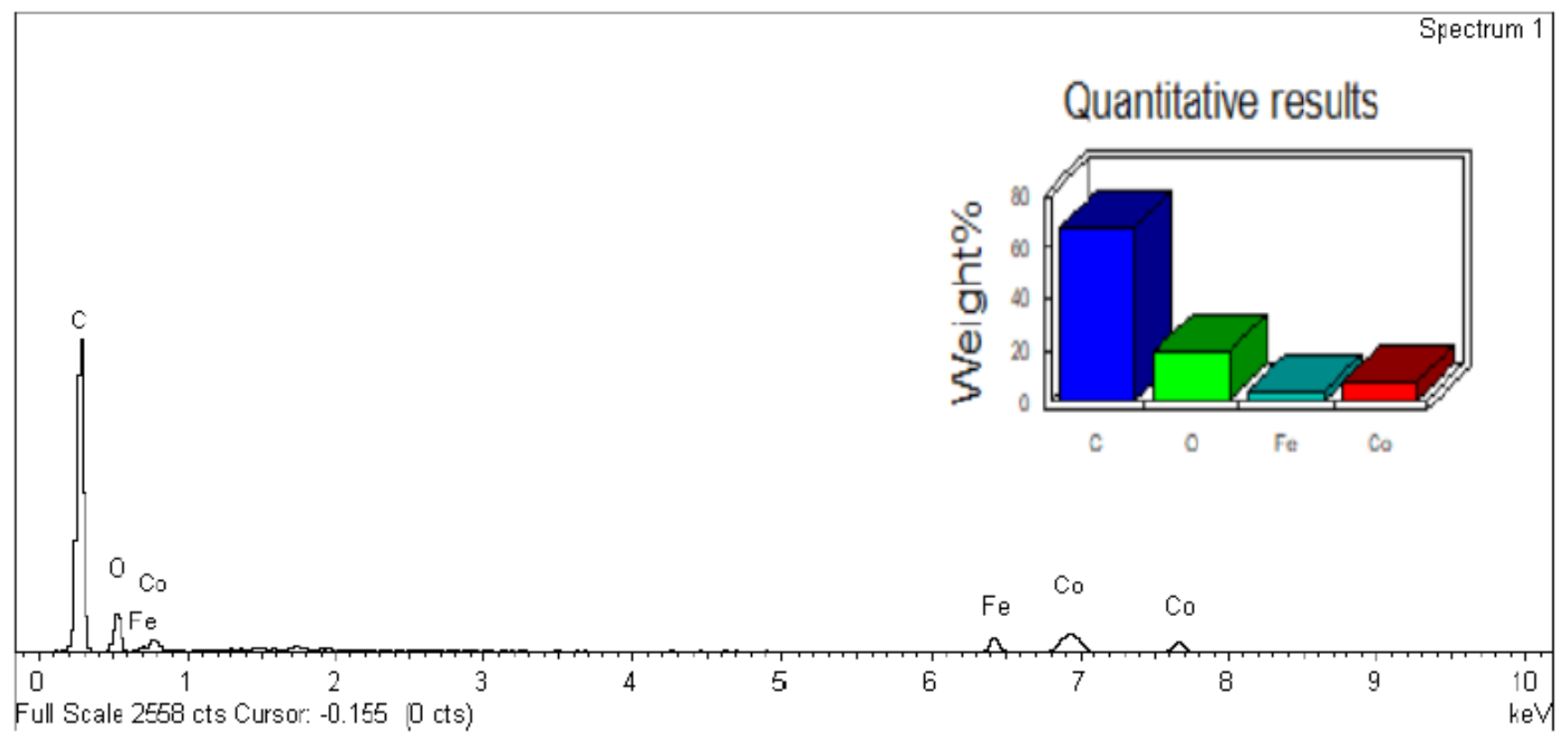

Fig. 3 EDX spectra of the $10 \mathrm{Co}-5 \mathrm{Fe} / \mathrm{AC}$ catalyst

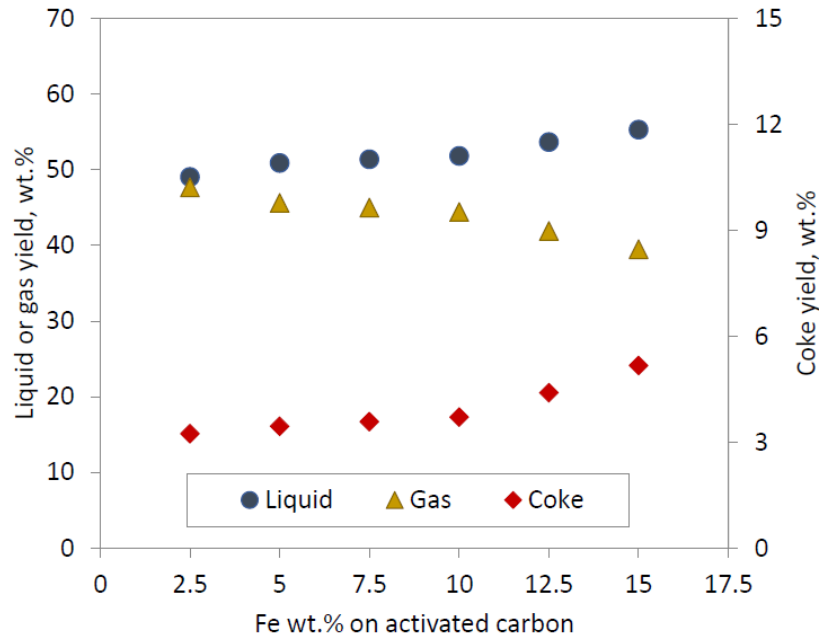

Fig. 4 Product yields obtained in catalytic cracking of WCO using Fe/AC catalysts $\left(450{ }^{\circ} \mathrm{C}\right.$; WHSV $9 \mathrm{hr}^{-1}$; sample collected at $\left.30 \mathrm{~min}\right)$

feed contains $37.03 \%$ palmitic acid $\left(\mathrm{C}_{16}\right)$ and $62.97 \%$ oleic acid $\left(\mathrm{C}_{18}\right)$. Although large amount of the WCO (>44 wt.\%) being converted to gas and coke, there were significant amount of hydrocarbon formed and detected in the liquid product. Fig. 5 shows the liquid $\mathrm{C}_{5}-\mathrm{C}_{20}$ hydrocarbon yield obtained with $\mathrm{Fe} / \mathrm{AC}$ with different Fe loading.

The liquid products were obviously dominated by heavier hydrocarbon $\left(\mathrm{C}_{13}-\mathrm{C}_{20}\right)$ fractions with carbon chain length in the range of fatty acids in the $\mathrm{WCO}\left(\mathrm{C}_{16}\right.$ and $\left.\mathrm{C}_{18}\right)$ which is also in agreement with [18]. The liquid $\mathrm{C}_{5}-\mathrm{C}_{12}$ hydrocarbons yields obtained were between 17-23\% with the highest obtained by $10-\mathrm{Fe} / \mathrm{AC}$. The $\mathrm{C}_{13}-\mathrm{C}_{20}$ hydrocarbon yield increased starting from 2.5 wt.\% Fe until 7.5 wt.\% Fe (64\%) and then it dropped subsequently with

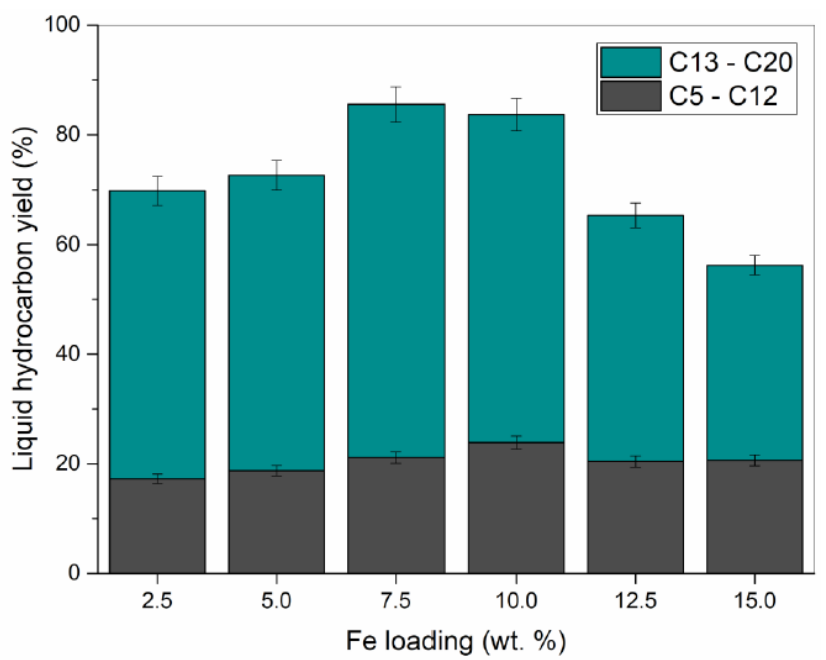

Fig. 5 Liquid $\mathrm{C}_{5}-\mathrm{C}_{20}$ hydrocarbon yield in catalytic cracking of WCO using Fe/AC with $2.5-15$ wt.\% Fe loading $\left(450{ }^{\circ} \mathrm{C}\right.$; WHSV 9 hr $^{-1}$;

sample collected at $30 \mathrm{~min})$

further increase in Fe loading till 15 wt.\% (at $35 \%$ ). In the present study, Fe loading $>10 \mathrm{wt} . \%$ had little effect on the liquid $\mathrm{C}_{5}-\mathrm{C}_{12}$ hydrocarbons yield.

Fig. 6 shows the carbon number selectivity for $\mathrm{C}_{5}-\mathrm{C}_{20}$ hydrocarbons content in liquid product obtained by using the Fe/AC catalysts with different Fe loading. Liquid product exhibited more selectivity for $\mathrm{n}-\left(\mathrm{C}_{15}+\mathrm{C}_{17}\right)$ hydrocarbons and it could be deduced as the consequence of deoxygenation of palmitic acid $\left(\mathrm{C}_{16}\right)$ and oleic acid $\left(\mathrm{C}_{18}\right)$ in WCO via decarboxylation and/or decarbonylation [12]. The highest $n-\left(C_{15}+C_{17}\right)$ hydrocarbons selectivity (52\%) was detected for 7.5-Fe/AC which was also in line with the highest liquid yield obtained. Selectivity towards heavier 


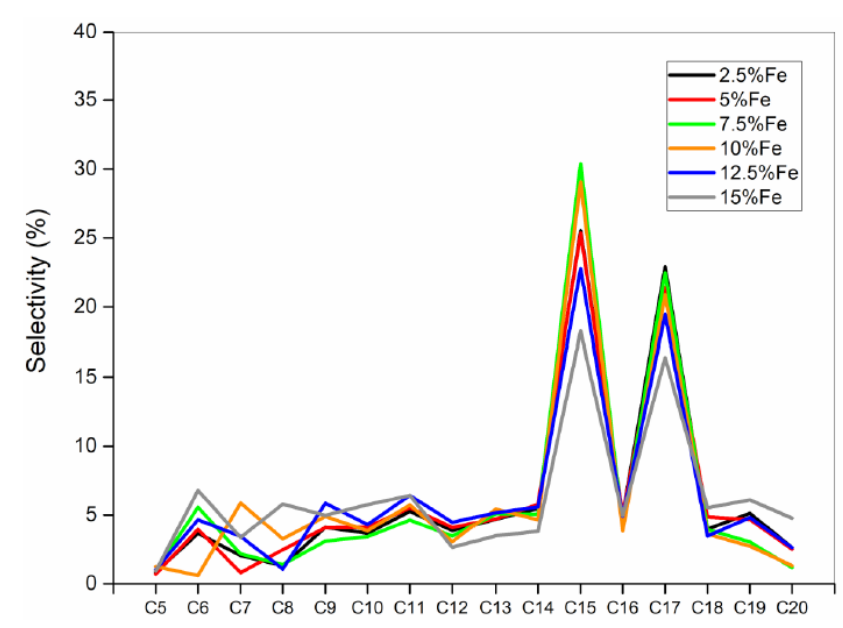

Fig. 6 Carbon number selectivity for $\mathrm{C}_{5}-\mathrm{C}_{20}$ hydrocarbons in liquid product obtained in catalytic cracking of WCO using Fe/AC with 2.5-15 wt. $\% \mathrm{Fe}\left(450^{\circ} \mathrm{C}\right.$; WHSV $9 \mathrm{hr}^{-1}$ and sample collected at $\left.30 \mathrm{~min}\right)$

hydrocarbons $\left(\mathrm{C}_{18}-\mathrm{C}_{20}\right)$ were higher relatively for 15-Fe/AC. This could be deduced as higher Fe loading is selective towards heavier hydrocarbon compounds. It was also believed that the catalyst had partially deactivated due to high coke formation that covered the active sites.

\subsubsection{Co loading}

$\mathrm{Co} / \mathrm{AC}$ catalysts with different Co loading were also examined for their performance in catalytic cracking of WCO. Fig. 7 shows the liquid, gas and coke yield obtained for catalytic cracking of WCO using Co/AC with 2.5-15 wt.\% Co loading.

There was an optimum point for liquid yield in the present Co loading study range. Liquid yield increased from 48 wt.\% to 59 wt.\% with increasing Co loading from

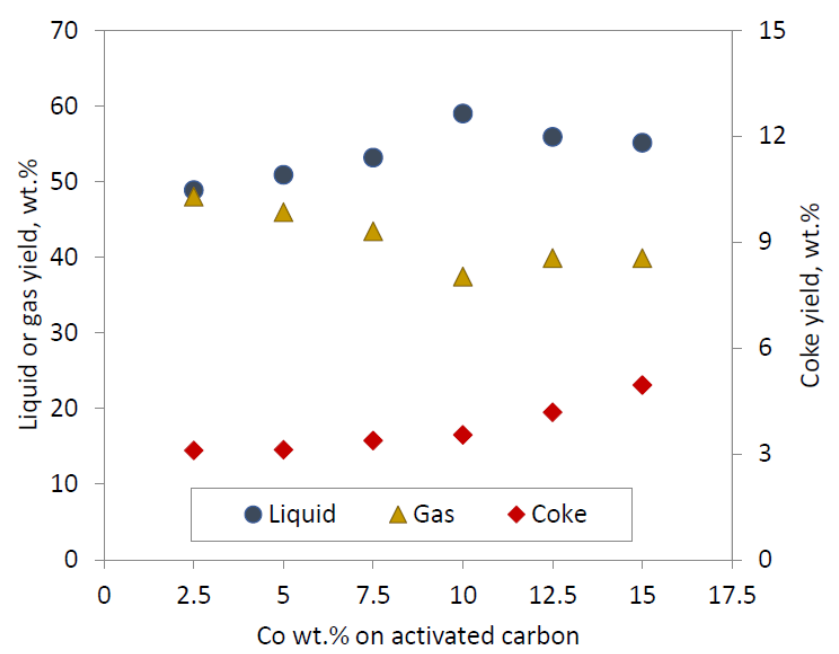

Fig. 7 Liquid, gas and coke yield obtained in catalytic cracking of WCO using $\mathrm{Co} / \mathrm{AC}$ with different Co loading $\left(450^{\circ} \mathrm{C}\right.$; WHSV $9 \mathrm{hr}^{-1}$; sample collected at $30 \mathrm{~min}$ )
2.5 wt. $\%$ to $10 \mathrm{wt} . \%$ and then reduced to $55 \mathrm{wt} . \%$ with higher Co loading ( $>10 \mathrm{wt} . \%)$ for $\mathrm{Co} / \mathrm{AC}$ catalysts. This can be related to increased coke yield ( $>4 \mathrm{wt} . \%$ ) in the presence of more Co oxide which blocked access of triglycerides to the active sites for reaction [19]. However, the lowest fatty acid concentration was detected in liquid product by 12.5 $\mathrm{Co} / \mathrm{AC}$ for the $\mathrm{Co} / \mathrm{AC}$ catalysts. The liquid $\mathrm{C}_{5}-\mathrm{C}_{20}$ hydrocarbon yield of $\mathrm{Co} / \mathrm{AC}$ catalysts with different Co loading is given in Fig. 8. The liquid hydrocarbon yield increased from $66 \%$ with $2.5-\mathrm{Co} / \mathrm{AC}$ to $79 \%$ with $10-\mathrm{Co} / \mathrm{AC}$. The liquid hydrocarbon yield remained at $79 \%$ with 12.5 $\mathrm{Co} / \mathrm{AC}$ and then reduced to $53 \%$ with $15-\mathrm{Co} / \mathrm{AC}$ catalyst.

Excess metal loading may have caused accumulation of the active phase at pore inlet that reduced its contact with reactant molecules [20]. Similar trend as the liquid hydrocarbon yield, was observed for liquid $\mathrm{C}_{5}-\mathrm{C}_{14}$ hydrocarbons (max. $25 \%$ by $12.5-\mathrm{Co} / \mathrm{AC}$ ). This suggested that more $\mathrm{Co}$ loading in $\mathrm{Co} / \mathrm{AC}$ induced more cracking activity to generate lighter compounds. The highest $\mathrm{C}_{13}-\mathrm{C}_{20}$ hydrocarbon yield (57\%) was obtained by $7.5-\mathrm{Co} / \mathrm{AC}$ which then dropped with higher Co loading beyond that.

Fig. 9 shows carbon number selectivity for $\mathrm{C}_{5}-\mathrm{C}_{20}$ hydrocarbons in the liquid product of $\mathrm{Co} / \mathrm{AC}$ catalysts.

The selectivity of $\mathrm{n}-\left(\mathrm{C}_{15}+\mathrm{C}_{17}\right)$ hydrocarbons $(57 \%)$ obtained by 7.5-Co/AC was the highest. $12.5-\mathrm{Co} / \mathrm{AC}$ catalyst exhibited high selectivity towards liquid $\mathrm{C}_{5}-\mathrm{C}_{14}$ hydrocarbons (34\%) via more cracking activity. 7.5-Co/AC and 7.5-Fe/AC both contributed to better deoxygenation but higher loading of Co increased cracking activity with higher $\mathrm{C}_{5}-\mathrm{C}_{12}$ lighter hydrocarbons selectivity whereas higher Fe loading leading to heavier products. These

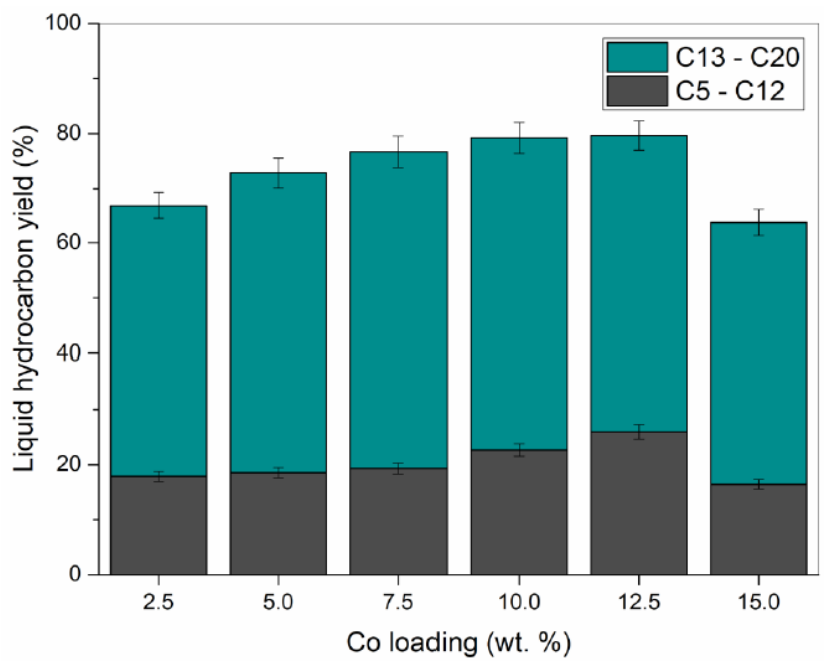

Fig. 8 Liquid $\mathrm{C}_{5}-\mathrm{C}_{20}$ hydrocarbon yield in catalytic cracking of WCO using $\mathrm{Co} / \mathrm{AC}$ with $2.5-15$ wt.\% Co loading $\left(450{ }^{\circ} \mathrm{C}\right.$; WHSV $9 \mathrm{hr}^{-1}$ and 30 min) 


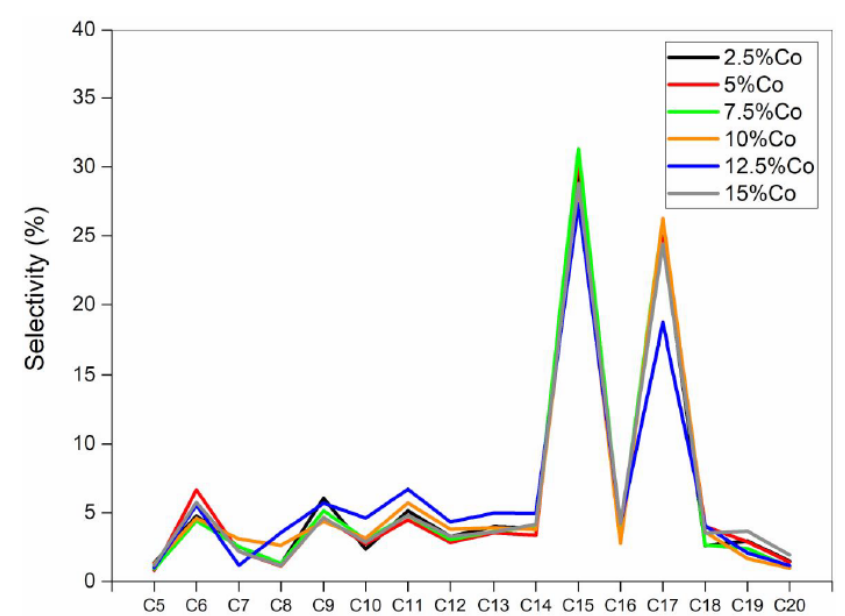

Fig. 9 Carbon number selectivity for $\mathrm{C}_{5}-\mathrm{C}_{20}$ hydrocarbons in liquid product obtained in catalytic cracking of WCO using $\mathrm{Co} / \mathrm{AC}$ with $2.5-15$ wt. $\%$ Co loading $\left(450^{\circ} \mathrm{C}\right.$; WHSV $9 \mathrm{hr}^{-1}$ and $\left.30 \mathrm{mins}\right)$

observations had led to the investigation of bimetallic $\mathrm{Co}-\mathrm{Fe} / \mathrm{AC}$ catalysts to further improve the liquid product and hydrocarbon yield with better selectivity towards $\mathrm{C}_{5}-\mathrm{C}_{12}$ range hydrocarbons or $\mathrm{C}_{13}-\mathrm{C}_{20}$ fraction.

\subsection{Bimetallic Co-Fe/AC}

Performance of bimetallic Co-Fe/AC catalysts in catalytic cracking of WCO was investigated. A total Co and Fe loading of $15 \mathrm{wt} . \%$ on $\mathrm{AC}$ was used. Co loading increased from $2.5 \mathrm{wt} . \%$ to $12.5 \mathrm{wt} . \%$ with the reduction in Fe loading from 12.5 wt. $\%$ to 2.5 wt. $\%$ on AC. Fig. 10 shows the product yields in catalytic cracking of WCO using bimetallic $\mathrm{Co}-\mathrm{Fe} /$ $\mathrm{AC}$ catalysts with various $\mathrm{Co}-\mathrm{Fe}$ loading combinations.

The highest liquid yield ( 65 wt.\%) was obtained by using $10 \mathrm{Co}-5 \mathrm{Fe} / \mathrm{AC}$ with the lowest gaseous product yield of 30 wt.\%. Liquid yield increased to the maximum with Co loading (from 2.5 to $10 \mathrm{wt} . \%$ ) and then dropped with further increase of Co loading on AC. Meanwhile, increase in coke formation (from 3.99 to $4.93 \mathrm{wt} . \%$ ) was noted with Fe loading from $2.5 \mathrm{wt} . \%$ to $12.5 \mathrm{wt} . \%$ in catalyst. Nevertheless, the coke yield was less than $5 \mathrm{wt} . \%$ for all Co-Fe/AC catalysts used in the present study. Although similar trend was exhibited for the single metal-AC catalysts (Co/AC), the bimetallic $\mathrm{Co}-\mathrm{Fe} / \mathrm{AC}$ catalysts led to higher liquid yield with better fatty acid conversion. The lowest fatty acid component ( $4.36 \%$ ) obtained by bimetallic catalyst (10Co-5Fe/AC) was lower than that by the single metal-AC catalysts with 7.5-Fe/AC (21.9\%) and 12.5-Co/AC (14.2\%) catalysts.

The liquid hydrocarbon yield obtained in catalytic cracking using $\mathrm{Co}-\mathrm{Fe} / \mathrm{AC}$ catalysts is illustrated in Fig. 11. The highest hydrocarbon yield of $93 \%$ was achieved with bimetallic $10 \mathrm{Co}-5 \mathrm{Fe} / \mathrm{AC}$ which was higher than that for single

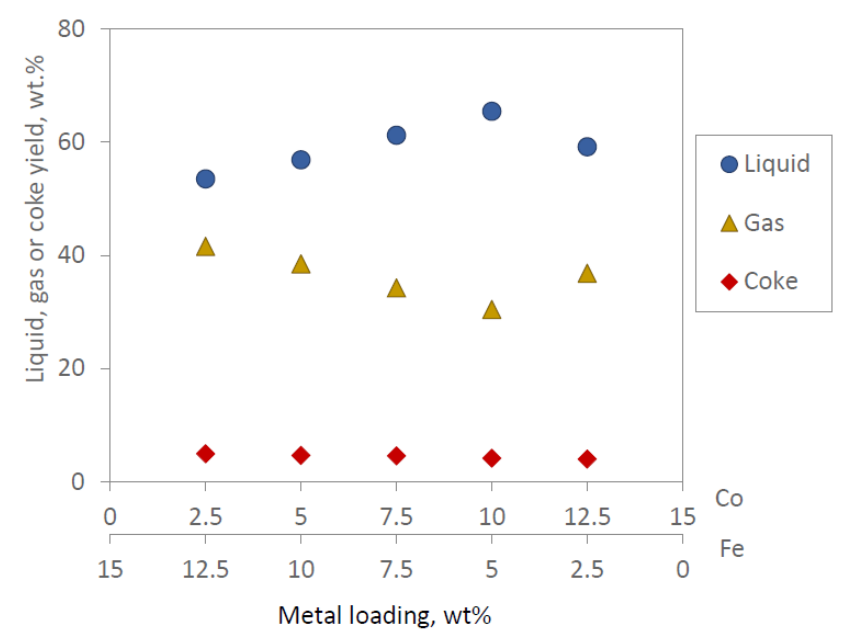

Fig. 10 Products yield obtained in catalytic cracking of WCO with $\mathrm{Co}-\mathrm{Fe} / \mathrm{AC}$ catalysts $\left(450^{\circ} \mathrm{C}\right.$; WHSV $9 \mathrm{hr}^{-1}$ and $\left.30 \mathrm{mins}\right)$

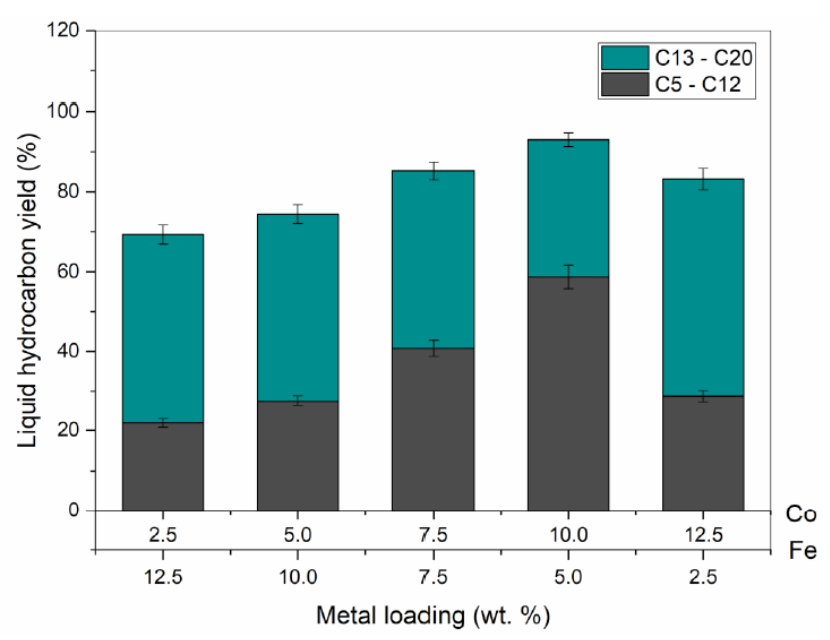

Fig. 11 Liquid $\mathrm{C}_{5}-\mathrm{C}_{20}$ hydrocarbon yield for $\mathrm{Co}-\mathrm{Fe} / \mathrm{AC}$ catalysts in catalytic cracking of WCO $\left(450{ }^{\circ} \mathrm{C}\right.$; WHSV $9 \mathrm{hr}^{-1}$ and $\left.30 \mathrm{mins}\right)$

metallic catalysts: 7.5 -Fe/AC (87 \%) and 12.5-Co/AC (79 \%) catalysts. Bimetal oxides improved catalytic performance of the activated carbon-based catalyst with more liquid product, fatty acid conversion and liquid hydrocarbon yield. This could be caused by the synergistic effect between $\mathrm{Co}$ and $\mathrm{Fe}$ oxides for more efficient cracking and deoxygenation reactions [12]. In the present study, it can be deduced that Co oxides contributed to high liquid yield and Fe oxide offered more liquid $\mathrm{C}_{5}-\mathrm{C}_{20}$ hydrocarbon yield in $10 \mathrm{Co}-5 \mathrm{Fe} / \mathrm{AC}$ catalyst. High cracking activity of the catalyst provided more liquid $\mathrm{C}_{5}-\mathrm{C}_{12}$ range hydrocarbons than $\mathrm{C}_{13}-\mathrm{C}_{20}$ hydrocarbon fraction [21]. This infers that the high yields in liquid $\mathrm{C}_{5}-\mathrm{C}_{12}$ hydrocarbons (58 \%) and $\mathrm{C}_{13}-\mathrm{C}_{20}$ hydrocarbons (34 \%) was due to high cracking and deoxygenation reactions consequences of synergy between $\mathrm{Fe}$ and $\mathrm{Co}$ in $10 \mathrm{Co}-5 \mathrm{Fe} / \mathrm{AC}$. The lowest liquid hydrocarbon yield (70 \%) along with the highest coke yield (4.93 wt.\%) was obtained by using $2.5 \mathrm{Co}-12.5 \mathrm{Fe} / \mathrm{AC}$ catalyst. Interestingly, the highest 
$\mathrm{C}_{13}-\mathrm{C}_{20}$ hydrocarbons yield (54 \%) was resulted by using $12.5 \mathrm{Co}-2.5 \mathrm{Fe} / \mathrm{AC}$ catalyst.

Fig. 12 shows the carbon number selectivity for hydrocarbons in liquid product of $\mathrm{Co}-\mathrm{Fe} / \mathrm{AC}$ catalysts. $10 \mathrm{Co}-5 \mathrm{Fe} /$ AC catalyst rendered $22 \% \mathrm{n}-\left(\mathrm{C}_{15}+\mathrm{C}_{17}\right)$ hydrocarbons selectivity and the maximum selectivity towards $\mathrm{n}-\left(\mathrm{C}_{15}+\mathrm{C}_{17}\right)$ hydrocarbons $(45 \%)$ was attained by $12.5 \mathrm{Co}-2.5 \mathrm{Fe} / \mathrm{AC}$. $\mathrm{n}-\left(\mathrm{C}_{15}+\mathrm{C}_{17}\right)$ hydrocarbons are considered as the direct products of decarboxylation and/or decarbonylation of palmitic acid $\left(\mathrm{C}_{16}\right)$ and oleic acid $\left(\mathrm{C}_{18}\right)$. The highest selectivity towards $\mathrm{n}-\left(\mathrm{C}_{15}+\mathrm{C}_{17}\right)$ hydrocarbons obtained by $\mathrm{Co}-\mathrm{Fe} / \mathrm{AC}$ catalysts was lower than that attained by $\mathrm{Co} / \mathrm{AC}$ and $\mathrm{Fe} /$ $\mathrm{AC}$ catalysts ( $>50 \%)$. This implies that $\mathrm{Co}-\mathrm{Fe} / \mathrm{AC}$ catalysts induced extensive cracking of the deoxygenated product to generate short-chain hydrocarbons [22]. High Co loading was found to increase cracking activities, for instance using $10 \mathrm{Co}-5 \mathrm{Fe} / \mathrm{AC}$ catalyst displayed $72 \%$ selectivity towards lighter hydrocarbons $\left(\mathrm{C}_{5}-\mathrm{C}_{14}\right)$ with lower $\mathrm{C}_{15}$ and $\mathrm{C}_{17}$ hydrocarbons selectivity (22\%). Both $\mathrm{Fe} / \mathrm{AC}$ and $\mathrm{Co} /$ $\mathrm{AC}$ enhanced deoxygenation. This can be observed especially in the catalytic cracking reactions with $7.5-\mathrm{Co} / \mathrm{AC}$ $(57 \%)$ and $7.5-\mathrm{Fe} / \mathrm{AC}(52 \%)$ which produced higher $\mathrm{n}-\mathrm{C}_{15}$ and $\mathrm{n}-\mathrm{C}_{17}$ hydrocarbons (Fig. 3 and Fig. 6).

Fig. 13 compares the composition of components in liquid products obtained for $10 \mathrm{Co}-5 \mathrm{Fe} / \mathrm{AC}, 12.5-\mathrm{Co} / \mathrm{AC}$ and 7.5-Fe/AC catalysts with high fatty acid conversion. The liquid product consisted of hydrocarbons and oxygenates such as alcohols, ketones, carboxylic acids and esters. The hydrocarbons were aliphatic compounds (alkanes and alkenes) with some cycloalkanes and aromatics.

Though $10 \mathrm{Co}-5 \mathrm{Fe} / \mathrm{AC}$ gave the highest liquid hydrocarbon yield, $12.5-\mathrm{Co} / \mathrm{AC}$ catalyst gave the highest alkanes

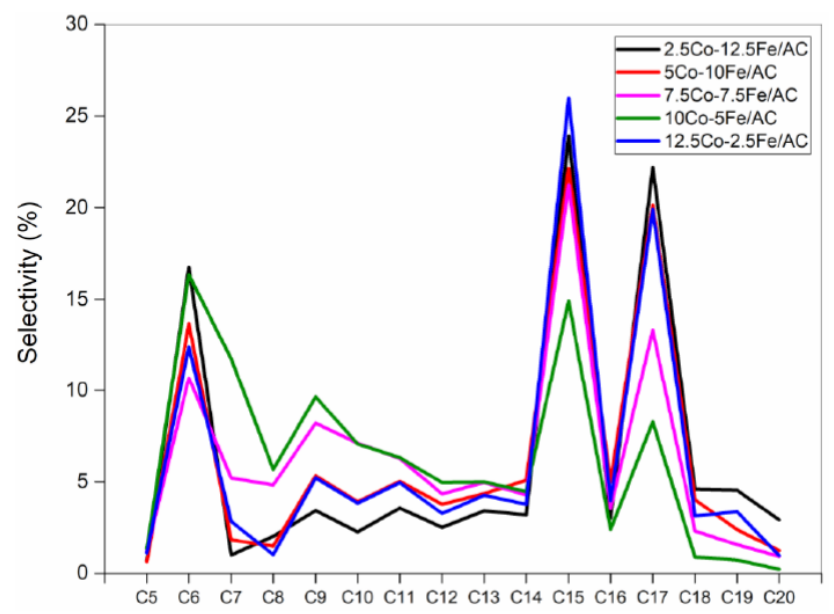

Fig. 12 Carbon number selectivity for hydrocarbons in liquid produced in catalytic cracking of WCO using Co-Fe/AC catalysts $\left(450{ }^{\circ} \mathrm{C}\right.$; WHSV $9 \mathrm{hr}^{-1}$ and $\left.30 \mathrm{~min}\right)$ yield $(56 \%)$ whereas the highest alkenes yield (33 \%) was attained by $7.5-\mathrm{Fe} / \mathrm{AC}$ catalyst. This could be caused by Fe oxide that favoured olefins formation via secondary cracking of the oxygenated compounds [23]. It also promoted secondary reactions such as cyclization and aromatization to form reasonably high cycloalkanes $(1.7 \%)$ and aromatics $(7.8 \%)$ relatively, which are coke precursors. The bimetallic oxide $10 \mathrm{Co}-5 \mathrm{Fe} / \mathrm{AC}$ catalyst had the least oxygenates content: carboxylic acid/fatty acid (4.36\%), ketone $(2.02 \%)$ and ester $(0.6 \%)$ with the highest aliphatic hydrocarbons yield ( $84 \%$ ). It showed better total deoxygenation activity than single metal oxides $\mathrm{Co} / \mathrm{AC}$ or $\mathrm{Fe} / \mathrm{AC}$ catalysts. Since it had the highest liquid yield and the liquid hydrocarbon yield, the influence of reaction factors such as temperature, feed flow rate and reaction period on the catalyst performance were investigated.

\subsection{Effect of reaction temperature}

The catalytic performance of $10 \mathrm{Co}-5 \mathrm{Fe} / \mathrm{AC}$ at different reaction temperature was tested. Table 1 shows the product yields for $10 \mathrm{Co}-5 \mathrm{Fe} / \mathrm{AC}$ catalyst in catalytic cracking of $\mathrm{WCO}$ at temperature range of $400-550^{\circ} \mathrm{C}$. The liquid yield decreased with increasing reaction temperature while the gaseous product (38 wt.\%) increased significantly due to extensive cracking [24]. More fatty acids were converted to other intermediates or products at a higher reaction temperature. On the other hand, coke formation was found to decrease with increasing temperature. This can be linked to decomposition of oil or the char formed on catalyst [25].

The coke yield (6 wt.\%) was higher at lower temperature $\left(400^{\circ} \mathrm{C}\right)$ where incomplete conversion of WCO could have caused deposition of residual substance on the catalyst. Fig. 14 shows liquid $\mathrm{C}_{5}-\mathrm{C}_{20}$ hydrocarbon yields

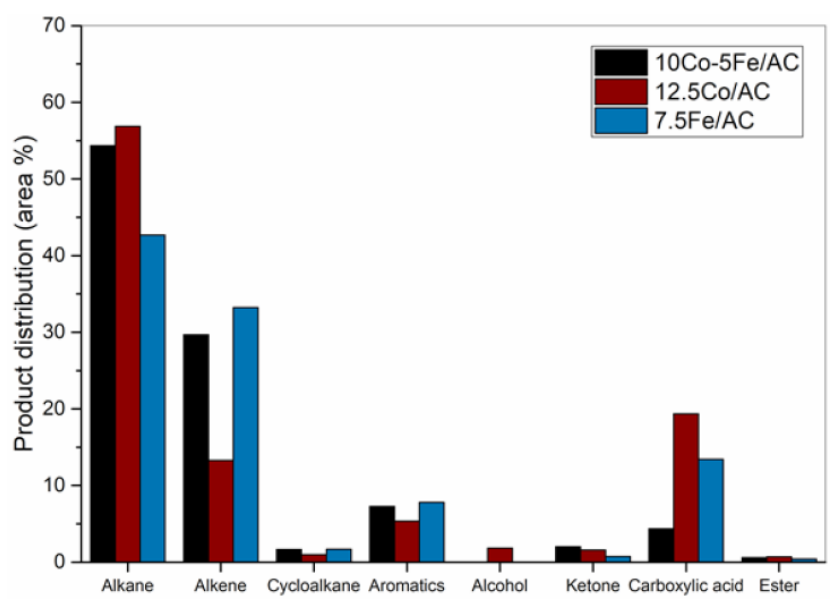

Fig. 13 Composition of components in liquid product obtained for $10 \mathrm{Co}-5 \mathrm{Fe} / \mathrm{AC}, 12.5-\mathrm{Co} / \mathrm{AC}$ and $7.5-\mathrm{Fe} / \mathrm{AC}$ catalysts 
Table 1 Product yields for $10 \mathrm{Co}-5 \mathrm{Fe} / \mathrm{AC}$ in catalytic cracking of WCO $\left(400-550^{\circ} \mathrm{C}\right.$; WHSV $9 \mathrm{hr}^{-1}$ and $\left.30 \mathrm{~min}\right)$

\begin{tabular}{lccc}
\hline $\begin{array}{l}\text { Temperature } \\
\left({ }^{\circ} \mathrm{C}\right)\end{array}$ & Liquid & Coke & Gas \\
\hline 400 & 76.65 & 6.17 & 17.18 \\
450 & 65.44 & 4.14 & 30.42 \\
500 & 61.52 & 3.88 & 34.60 \\
550 & 57.91 & 3.59 & 38.50 \\
\hline
\end{tabular}

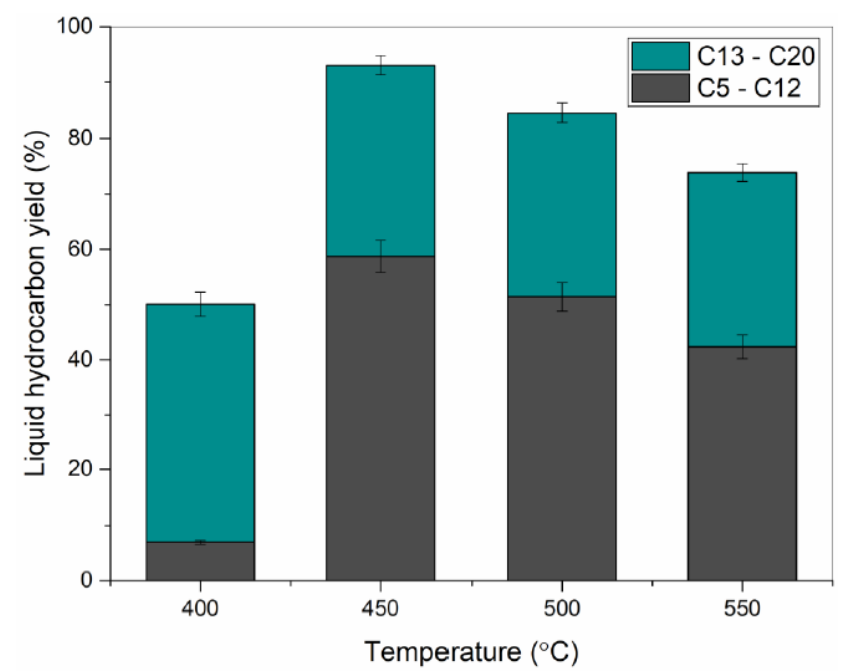

Fig. 14 Liquid $\mathrm{C}_{5}-\mathrm{C}_{20}$ hydrocarbon yield generated in catalytic cracking of WCO using $10 \mathrm{Co}-5 \mathrm{Fe} / \mathrm{AC}$ catalyst $\left(400-550{ }^{\circ} \mathrm{C}\right.$; WHSV $9 \mathrm{hr}^{-1}$ and $30 \mathrm{~min}$ )

obtained in catalytic cracking of WCO using $10 \mathrm{Co}-5 \mathrm{Fe} /$ $\mathrm{AC}$ at temperature range from 400 to $550{ }^{\circ} \mathrm{C}$.

Despite the highest liquid yield (76 wt.\%) obtained at $400{ }^{\circ} \mathrm{C}$, liquid $\mathrm{C}_{5}-\mathrm{C}_{20}$ hydrocarbon yield was the least $(50 \%)$ among the investigated temperature range. This could be due to insufficient reaction energy at the lower temperature to crack triglyceride in WCO to free fatty acids and further cracking the free fatty acids to hydrocarbon. $93 \%$ liquid hydrocarbon yield was attained at temperature of $450{ }^{\circ} \mathrm{C}$ which could have provided optimum heat energy for the reaction to occur at a better efficiency [26]. The liquid hydrocarbon yield dropped at temperature beyond $450{ }^{\circ} \mathrm{C}$ which could be due to excess heat that promoted undesired secondary reactions such as polyaromatization and condensation to produce heavy compounds [27]. It is observed that liquid $\mathrm{C}_{5}-\mathrm{C}_{12}$ hydrocarbons yield was higher than $\mathrm{C}_{13}-\mathrm{C}_{20}$ hydrocarbon fraction at reaction temperature $\geq 450{ }^{\circ} \mathrm{C}$. This can be explained with the occurrence of extensive cracking to lighter hydrocarbons [28]. Fig. 15 depicts the carbon number selectivity for hydrocarbons produced at reaction temperature in the range of $400-550{ }^{\circ} \mathrm{C}$.

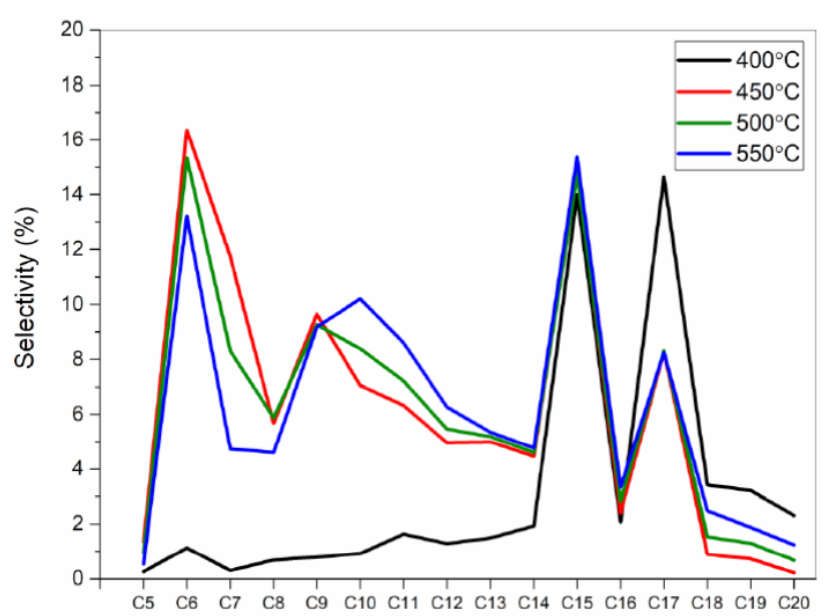

Fig. 15 Carbon number selectivity for hydrocarbons produced in catalytic cracking of WCO using $10 \mathrm{Co}-5 \mathrm{Fe} / \mathrm{AC}\left(400-550^{\circ} \mathrm{C}\right.$; WHSV $9 \mathrm{hr}^{-1} ; 30 \mathrm{~min}$

The highest $n-\left(\mathrm{C}_{15}+\mathrm{C}_{17}\right)$ hydrocarbons selectivity (57\%) was noted at $400{ }^{\circ} \mathrm{C}$ with the lowest $\mathrm{C}_{5}-\mathrm{C}_{14}$ hydrocarbons selectivity (20\%) which indicates cracking of $\mathrm{C}-\mathrm{O}$ bond (deoxygenation) require lower reaction energy than cracking of $\mathrm{C}-\mathrm{C}$ bond. The selectivity for lighter $\mathrm{C}_{5}-\mathrm{C}_{14}$ hydrocarbons increased with the rise in reaction temperature (450 to $550{ }^{\circ} \mathrm{C}$ ). Selectivity of both $\mathrm{C}_{5}-\mathrm{C}_{9}$ hydrocarbon $(44 \%)$ and $\mathrm{n}-\left(\mathrm{C}_{15}+\mathrm{C}_{17}\right)$ hydrocarbons were high at $450^{\circ} \mathrm{C}$ that catered for balanced decarboxylation/ decarbonylation and cracking reactions. Therefore, $450{ }^{\circ} \mathrm{C}$ seemed to be the optimum temperature in the present study.

\subsection{Effect of weight hourly space velocity of feed}

The activity of $10 \mathrm{Co}-5 \mathrm{Fe} / \mathrm{AC}$ in catalytic cracking of WCO at different feed rates were investigated too. Table 2 shows the liquid, gas and coke yields obtained in the reaction at WHSV between $7 \mathrm{hr}^{-1}$ and $10 \mathrm{hr}^{-1}$. The liquid yield increased with WHSV and the gas yield reduced with it. Formation of more gaseous product at lower feed rate was caused by increased residence time resulting from extended contact time between reactant and catalyst for higher cracking activity [29].

Coke yield also increased at higher WHSV. This phenomenon could have been caused by formation of residual

Table 2 Product yield for catalytic cracking of WCO using $10 \mathrm{Co}-5 \mathrm{Fe} /$ AC (WHSV: 7-10 $\mathrm{hr}^{-1} ; 450{ }^{\circ} \mathrm{C}$ and $30 \mathrm{~min}$ )

\begin{tabular}{lccc}
\hline Weight Hourly Space & \multicolumn{3}{c}{ Product Yield (wt. \%) } \\
Velocity $\left(\mathrm{hr}^{-1}\right)$ & Liquid & Coke & Gas \\
\hline 7 & 55.05 & 3.17 & 41.78 \\
8 & 62.89 & 3.57 & 33.55 \\
9 & 65.44 & 4.14 & 30.42 \\
10 & 65.75 & 5.90 & 28.35 \\
\hline
\end{tabular}


substances via incomplete conversion of WCO due to overloading of available active sites with excess reactant molecules.

The liquid $\mathrm{C}_{5}-\mathrm{C}_{20}$ hydrocarbon yield obtained is shown in Fig. 16. With the WHSV increasing, the yield of liquid $\mathrm{C}_{5}-\mathrm{C}_{20}$ hydrocarbon increased to the maximum at WHSV of $9 \mathrm{hr}^{-1}(93 \%)$ and then dropped after that at WHSV $10 \mathrm{hr}^{-1}$ (56\%). Maximum reaction efficiency was attained with sufficient reactant molecules introduced to available active sites of the catalyst. The liquid $\mathrm{C}_{5}-\mathrm{C}_{12}$ hydrocarbon yield had similar trend because secondary cracking reaction is minimized at higher feed rate (WHSV $10 \mathrm{hr}^{-1}$ ) [30].

Fig. 17 displays carbon number selectivity of liquid $\mathrm{C}_{5}-\mathrm{C}_{20}$ hydrocarbons produced for $10 \mathrm{Co}-5 \mathrm{Fe} / \mathrm{AC}$ in catalytic cracking of WCO at WHSV 7-10 hr-1. The n- $\left(\mathrm{C}_{15}+\mathrm{C}_{17}\right)$ selectivity decreased with increase in WHSV because the catalyst activity is optimum at $9 \mathrm{hr}^{-1}$ which gave the highest liquid hydrocarbon yield. However, the liquid $\mathrm{C}_{5}-\mathrm{C}_{14}$ hydrocarbons selectivity dropped at higher feed rate $\left(10 \mathrm{hr}^{-1}\right)$ that could have been due to lower contact time for the secondary cracking of deoxygenated $\left(\mathrm{C}_{15}\right.$ and $\left.\mathrm{C}_{17}\right)$ products.

\subsection{Catalyst deactivation over reaction period}

The catalytic cracking of $\mathrm{WCO}$ was proceeded at $450{ }^{\circ} \mathrm{C}$ and $9 \mathrm{hr}^{-1}$ for 300 mins to determine the deactivation of $10 \mathrm{Co}-5 \mathrm{Fe} / \mathrm{AC}$ catalyst. The results of liquid $\mathrm{C}_{5}-\mathrm{C}_{20}$ hydrocarbon yield and the remaining fatty acid in the liquid product collected for $5 \mathrm{hrs}$ of reaction are shown in Fig. 18. A significant amount of coke (6.81 wt.\%) was formed after 300 mins.

The catalyst activity was observed to reduce rapidly with decrease of hydrocarbon yield in liquid product (from

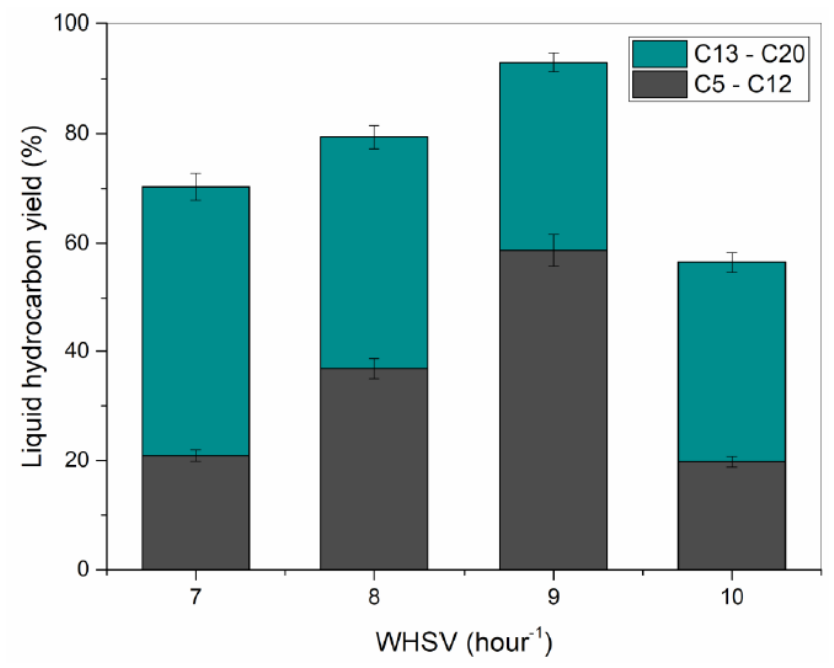

Fig. 16 Liquid $\mathrm{C}_{5}-\mathrm{C}_{20}$ hydrocarbon yield in catalytic cracking of WCO using $10 \mathrm{Co}-5 \mathrm{Fe} / \mathrm{AC}$ catalyst $\left(450^{\circ} \mathrm{C}\right.$; WHSV of $7-10 \mathrm{hr}^{-1}$ and $\left.30 \mathrm{~min}\right)$
$93 \%$ to $35 \%$ ) over $300 \mathrm{~min}$ of reaction. The fatty acid in liquid product was found to increase (from $4 \%$ to $31 \%$ ) over the period of time. Severe deactivation occurred as the operating time prolonged for the catalyst could be due to continuous coking which covered the active sites of the catalyst. Formation of carbonaceous substance covered its porous structure and hence blocked reactant molecules' access to the reaction sites [31]. Although the catalyst exhibited significant catalytic cracking performance, it experienced rapid deactivation due to coke deposition which makes it undesirable, and regeneration is critical.

\section{Conclusions}

High $\mathrm{C}_{5}-\mathrm{C}_{20}$ hydrocarbon yield was obtained with $7.5-\mathrm{Fe} /$ $\mathrm{AC}(87 \%)$ and $10-\mathrm{Co} / \mathrm{AC}(87 \%)$ catalysts. Incorporation of $\mathrm{Co}$ and $\mathrm{Fe}$ to activated carbon at ratio of 2:1 further increased the liquid yield (65\%) and liquid hydrocarbon

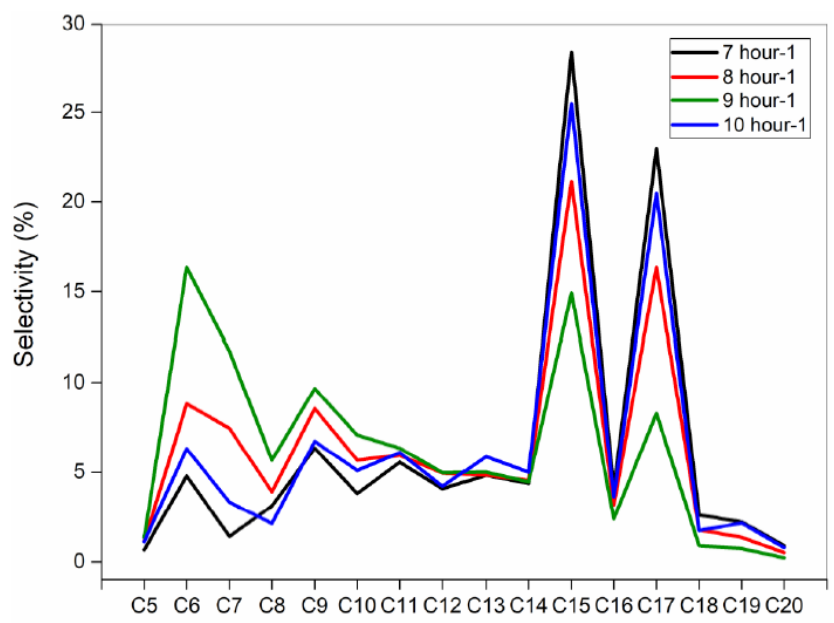

Fig. 17 Carbon number selectivity for hydrocarbons produced using $10 \mathrm{Co}-5 \mathrm{Fe} / \mathrm{AC}\left(450{ }^{\circ} \mathrm{C}\right.$; WHSV $7-10 \mathrm{hr}^{-1}$ and $\left.30 \mathrm{~min}\right)$

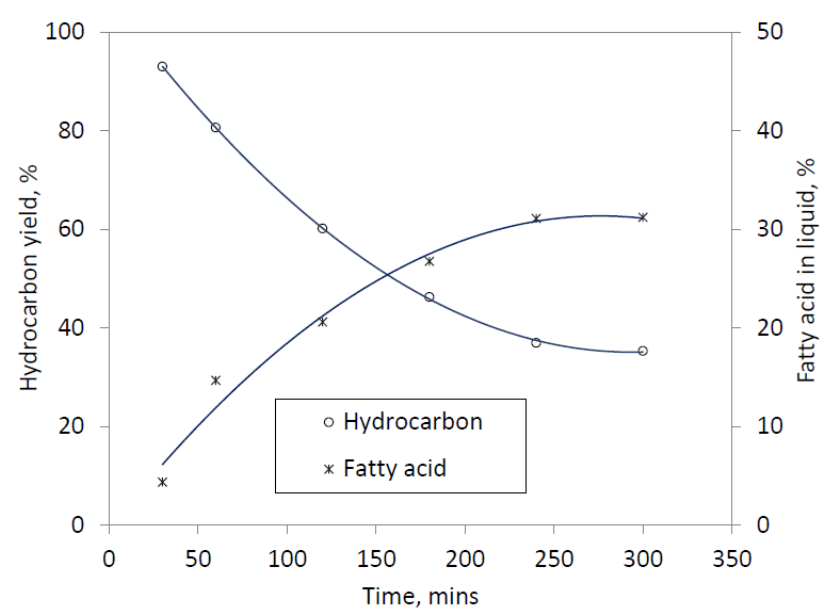

Fig. 18 Fatty acid conversion and liquid $\mathrm{C}_{5}-\mathrm{C}_{20}$ hydrocarbon yield of liquid product for catalytic cracking using $10 \mathrm{Co}-5 \mathrm{Fe} / \mathrm{AC}\left(450{ }^{\circ} \mathrm{C}\right.$; WHSV $\left.9 \mathrm{hr}^{-1} ; 30-300 \mathrm{~min}\right)$ 
yield (93\%), which was believed to be the synergistic interaction of the two metals in the catalyst that improved the catalyst activity on cracking and deoxygenation reactions. $\mathrm{Co}$ and Fe oxides contributed respectively to higher liquid product and more liquid hydrocarbon yield. Though good performance was obtained by the bimetallic catalyst, but it deactivated rapidly. Conventional catalyst regeneration via calcination in the air to burn off the coke formed

\section{References}

[1] Khodadadi, M. R., Malpartida, I., Tsang, C.-W., Lin, C. S. K., Len, C. "Recent advances on the catalytic conversion of waste cooking oil", Molecular Catalysis, 494, Article No. 111128, 2020. https://doi.org/10.1016/j.mcat.2020.111128

[2] Soh Kheang, L., Yuen May, C., Sit Foon, C., Ngan, M. A. "Recovery and conversion of palm olein-derived used frying oil to methyl esters for biodiesel", Journal of Oil Palm Research, 18, pp. 247-252, 2006.

[3] Chiaramonti, D., Buffi, M., Rizzo, A. M., Prussi, M., Martelli, F. "Bio-Hydrocarbons through Catalytic Pyrolysis of Used Cooking Oils: Towards sustainable jet and road fuels", Energy Procedia, 82, pp. 343-349, 2015. https://doi.org/10.1016/j.egypro.2015.11.800

[4] Zhao, X., Wei, L., Cheng, S., Julson, J. "Review of Heterogeneous Catalysts for Catalytically Upgrading Vegetable Oils into Hydrocarbon Biofuels", Catalysts, 7(3), pp. Article No. 83, 2017. https://doi.org/10.3390/catal7030083

[5] Clohessy, J., Kwapinski, W. "Carbon-Based Catalysts for Biodiesel Production-A Review", Applied Sciences, 10(3), Article No. 918, 2020.

https://doi.org/10.3390/app10030918

[6] Sadeek, S. A., Mohammed, E. A., Shaban, M., Abou Kana, M. T. H., Negm, N. A. "Synthesis, characterization and catalytic performances of activated carbon-doped transition metals during biofuel production from waste cooking oils", Journal of Molecular Liquids, 306, Article No. 112749, 2020.

https://doi.org/10.1016/j.molliq.2020.112749

[7] Omar, R., Robinson, J. P. "Conventional and microwave-assisted pyrolysis of rapeseed oil for bio-fuel production", Journal of Analytical and Applied Pyrolysis, 105, pp. 131-142, 2014. https://doi.org/10.1016/j.jaap.2013.10.012

[8] Lam, S. S., Wan Mahari, W. A., Jusoh, A., Chong, C. T., Lee, C. L., Chase, H. A. "Pyrolysis using microwave absorbents as reaction bed: An improved approach to transform used frying oil into biofuel product with desirable properties", Journal of Cleaner Production, 147, pp. 263-272, 2017. https://doi.org/10.1016/j.jclepro.2017.01.085

[9] Lam, S. S., Wan Mahari, W. A., Cheng, C. K., Omar, R., Chong, C. T., Chase, H. A. "Recovery of diesel-like fuel from waste palm oil by pyrolysis using a microwave heated bed of activated carbon", Energy, 115, pp. 791-799, 2016. https://doi.org/10.1016/j.energy.2016.09.076 would cause carbon decomposition into ash [32] and is not suitable for this carbon-based catalyst. Regeneration of carbon-based catalyst warrants further investigation [33].

\section{Acknowledgement}

This study was supported by Ministry of Higher Education Malaysia under FRGS grant (A/C: 203. PJKIMIA. 6071445).

[10] Natewong, P., Murakami, Y., Tani, H., Asami, K. "Effect of Support Material on MgO-Based Catalyst for Production of New Hydrocarbon Bio-Diesel", American Scientific Research Journal for Engineering, Technology, and Sciences (ASRJETS), 22(1), pp. 153-165, 2016.

[11] Yigezu, Z. D., Muthukumar, K. "Catalytic cracking of vegetable oil with metal oxides for biofuel production", Energy Conversion and Management, 84, pp. 326-33, 2014. https://doi.org/10.1016/j.enconman.2014.03.084

[12] Abdulkareem-Alsultan, G., Asikin-Mijan, N., Mustafa-Alsultan, G., Lee, H. V., Wilson, K., Taufiq-Yap, Y. H. "Efficient deoxygenation of waste cooking oil over $\mathrm{Co}_{3} \mathrm{O}_{4}-\mathrm{La}_{2} \mathrm{O}_{3}$-doped activated carbon for the production of diesel-like fuel", RSC Advances, 10(9), pp. 4996-5009, 2020. https://doi.org/10.1039/C9RA09516K

[13] Gamal, M. S., Asikin-Mijan, N., Khalit, W. N. A. W., Arumugam, M., Izham, S. M., Taufiq-Yap, Y. H. "Effective catalytic deoxygenation of palm fatty acid distillate for green diesel production under hydrogen-free atmosphere over bimetallic catalyst CoMo supported on activated carbon", Fuel Processing Technology, 208, Article No. 106519, 2020.

https://doi.org/10.1016/j.fuproc.2020.106519

[14] Asikin-Mijan, N., Rosman, N. A., Kareem-Alsultan, G. A., Mastuli, M. S., Lee, H. V., ..., Taufiq-Yap, Y. H. "Production of renewable diesel from Jatropha curcas oil via pyrolytic-deoxygenation over various multi-wall carbon nanotube-based catalysts", Process Safety and Environmental Protection, 142, pp. 336-349, 2020.

https://doi.org/10.1016/j.psep.2020.06.034

[15] Kusworo, T. D., Widayat, W., Mahadita, A. F., Firizqina, D., Utomo, D. P. "Bio-oil and Fuel Gas Production from Agricultural Waste via Pyrolysis: A Comparative Study of Oil Palm Empty Fruit Bunches (OPEFB) and Rice Husk", Periodica Polytechnica Chemical Engineering, 64(2), pp. 179-191, 2020. https://doi.org/10.3311/PPch.14553

[16] Shah, I., Adnan, R., Alsultan, A. G., Taufiq-Yap, Y. H. "Catalytic conversion of waste cooking oil into biodiesel using functionally advanced recyclable iron-impregnated activated carbon materials", Journal of Dispersion Science and Technology, 2020. https://doi.org/10.1080/01932691.2020.1850292

[17] Zhang, M., Sun, A., Meng, Y., Wang, L., Jiang, H., Li, G. "Catalytic Performance of Biomass Carbon-Based Solid Acid Catalyst for Esterification of Free Fatty Acids in Waste Cooking Oil", Catalysis Surveys from Asia, 19, pp. 61-67, 2015. https://doi.org/10.1007/s10563-014-9182-y 
[18] Nanda, S., Rana, R., Hunter, H. N., Fang, Z., Dalai, A. K., Kozinski, J. A. "Hydrothermal catalytic processing of waste cooking oil for hydrogen-rich syngas production", Chemical Engineering Science, 195, pp. 935-945, 2019. https://doi.org/10.1016/j.ces.2018.10.039

[19] Li, C., Ma, J., Xiao, Z., Hector, S. B., Liu, R., Zuo, S., Xie, X., Zhang, A., Wu, H., Liu, Q. "Catalytic cracking of Swida wilsoniana oil for hydrocarbon biofuel over Cu-modified ZSM-5 zeolite", Fuel, 218, pp. 59-66, 2018. https://doi.org/10.1016/j.fuel.2018.01.026

[20] Wu, J., Shi, J., Fu, J., Leidl, J. A., Hou, Z., Lu, X. "Catalytic Decarboxylation of Fatty Acids to Aviation Fuels over Nickel Supported on Activated Carbon", Scientific Reports, 6, Article number: 27820, 2016.

https://doi.org/10.1038/srep27820

[21] Negm, N. A., Rabie, A. M., Mohammed, E. A. "Molecular interaction of heterogeneous catalyst in catalytic cracking process of vegetable oils: chromatographic and biofuel performance investigation", Applied Catalysis B: Environmental, 239, pp. 36-45, 2018. https://doi.org/10.1016/j.apcatb.2018.07.070

[22] Santos, M. R., Arias, S., Padilha, J. F., Carneiro, M. C. N., Sales, E. A., Pacheco, J. G. A., Fréty, R. "Catalytic cracking of palmitic and oleic acids pre-adsorbed on $\gamma$-alumina", Catalysis Today, 344, pp. 234-239, 2020.

https://doi.org/10.1016/j.cattod.2019.04.005

[23] Mancio, A. A., da Costa, K. M. B., Ferreira, C. C., Santos, M. C., Lhamas, D. E. L., ..., Machado, N. T. "Thermal catalytic cracking of crude palm oil at pilot scale: Effect of the percentage of $\mathrm{Na} 2 \mathrm{CO} 3$ on the quality of biofuels", Industrial Crops and Products, 91, pp. $32-43,2016$. https://doi.org/10.1016/j.indcrop.2016.06.033

[24] Binnal, P., Mali, V. S., Karjekannavar, S. P., Mogaveera, S. R. "Enhancing Gasoline Range Hydrocarbons by Catalytic Co-pyrolysis of Rice Husk with Low Density Polyethylene (LDPE) Using Zeolite Socony Mobil\#5(ZSM-5)", Periodica Polytechnica Chemical Engineering, 64(2), pp. 221-229, 2020.

https://doi.org/10.3311/PPch.13850

[25] Durić, S. N., Željko, L., Kosanić, T. R., Ćeranić, M. B., Milotić, M. M., Brankov, S. D. "Experimental investigation of pyrolysis process of agricultural biomass mixture", Periodica Polytechnica Chemical Engineering, 58(2), pp. 141-147, 2014.

https://pp.bme.hu/ch/article/view/7199
[26] Doronin, V. P., Potapenko, O. V., Lipin, P. V., Sorokina, T. P. "Catalytic cracking of vegetable oils and vacuum gas oil", Fuel, 106, pp. 757-765, 2013. https://doi.org/10.1016/j.fuel.2012.11.027

[27] Malleswara Rao, T. V., Dupain, X., Makkee, M. "Fluid catalytic cracking: Processing opportunities for Fischer-Tropsch waxes and vegetable oils to produce transportation fuels and light olefins", Microporous and Mesoporous Materials, 164, pp. 148-163, 2012. https://doi.org/10.1016/j.micromeso.2012.07.016

[28] Heracleous, E., Iliopoulou, E. F., Drakaki, K., Papapetrou, M. C., Iatridis, D. K., Lappas, A. A. "Upgrading of biomass-derived liquids in a biorefinery context: Hydroisomerization and fluid catalytic cracking of heavy naphtha on bench and pilot scale", Catalysis Today, 2020. https://doi.org/10.1016/j.cattod.2020.08.006

[29] Pham, L. H. K., Tran, V. T. T., Kongparakul, S., Reubroycharoen, P., Karnjanakom, S., Guan, G., Samart, C. "Formation and activity of activated carbon supported Ni 2 P catalysts for atmospheric deoxygenation of waste cooking oil", Fuel Processing Technology, 185, pp. 117-125, 2019.

https://doi.org/10.1016/j.fuproc.2018.12.009

[30] Rezaei, P. S., Shafaghat, H., Daud, W. M. A. W. "Production of green aromatics and olefins by catalytic cracking of oxygenate compounds derived from biomass pyrolysis: A review", Applied Catalysis A: General, 469, pp. 490-511, 2014.

https://doi.org/10.1016/j.apcata.2013.09.036

[31] Santillan-Jimenez, E., Morgan, T., Lacny, J., Mohapatra, S., Crocker, M. "Catalytic deoxygenation of triglycerides and fatty acids to hydrocarbons over carbon-supported nickel", Fuel, 103, pp. 1010-1017, 2013. https://doi.org/10.1016/j.fuel.2012.08.035

[32] Yang, C., Florent, M., de Falco, G., Fan, H., Bandosz, T. J. " $\mathrm{ZnFe}_{2} \mathrm{O}_{4} /$ activated carbon as a regenerable adsorbent for catalytic removal of H2S from air at room temperature", Chemical Engineering Journal, 394, Article No. 124906, 2020. https://doi.org/10.1016/j.cej.2020.124906

[33] Diaz, E., Mohedano, A. F., Casas, J. A., Rodriguez, J. J. "Analysis of the deactivation of $\mathrm{Pd}, \mathrm{Pt}$ and $\mathrm{Rh}$ on activated carbon catalysts in the hydrodechlorination of the MCPA herbicide", Applied Catalysis B: Environmental, 181, pp. 429-435, 2016. https://doi.org/10.1016/j.apcatb.2015.08.008 